\title{
Soft Tissue Sarcoma Pathologic Distant Metastasis TNM Finding v7
}

National Cancer Institute

\section{Source}

National Cancer Institute. Soft Tissue Sarcoma Pathologic Distant Metastasis TNM

Finding V7. NCI Thesaurus. Code C88464.

A pathologic finding about one or more characteristics of soft tissue sarcoma, following the rules of the TNM AJCC v7 classification system as they pertain to distant metastases. There is no pathologic M0 for soft tissue sarcoma. 